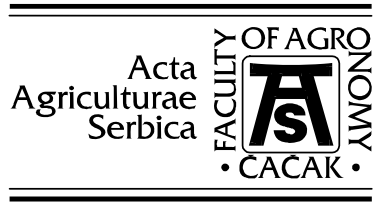

\title{
Relationship between milk production and metabolic adaptation in dairy cows during heat stress
}

\author{
Mira Majkić ${ }^{1}$, Marko R. Cincović ${ }^{1}$, Branislava Belić ${ }^{1}$, \\ Nada Plavša ${ }^{1}$, Ivana Lakić ${ }^{1}$, Miodrag Radinović ${ }^{1}$ \\ ${ }^{1}$ University of Novi Sad, Faculty of Agriculture, Department of Veterinary \\ Medicine, Laboratory of Pathophysiology, Novi Sad, Serbia \\ Corresponding author: mcincovic@gmail.com
}

\begin{abstract}
The aim of this study is to determine correlation between change in milk production and metabolic adaptation of cows during heat-stress. Experiment included 30 Holstein-Frisian cows. Cows exposed to heat-stress, which is expressed in high THI index, have lower milk production, higher concentration of insulin and lover concentrations of glucose and NEFA. Indexes of insulin resistance-RQUICKI, insulin: glucose and insulin: NEFA relations are higher in cows under heat stress. Grouping cows in accordance to reduced milk yield have showed that trend of reduction of glucose and NEFA levels, followed by increased insulin level, higher RQUICKI, greater insulin: glucose and insulin: NEFA ratios, started and increased during the reduction in milk production. Among this, significant correlation was founded between these parameters and milk yield. Significant correlation was also noted between those parameters. Change in metabolic value is of great importance for prediction of cows that would have decreased milk yield (above 18\%). With almost $90 \%$ certainty cows with great reduction in milk yield can be detected. These cows have had following relative changes in values of metabolic parameters during heat-stress compared to thermo-neutral period: insulin increased for $\geq 12.5 \%$, reduction in NEFA values for $\leq 14.1 \%$, reduction in glucose for $21.5 \%$, RQUICKI index increased for $\geq 9.6 \%$, insulin: NEFA ratio increased for $\geq 20.1 \%$ and insulin: glucose for $\geq 20.3 \%$. Dynamical changes in metabolites and insulin resistance
\end{abstract}


values have great influence on milk yield in cows under heat stress. Decreasing in glucoses followed by increased insulin level and increased insulin sensitivity indicate that glucose is transferred from udder to other tissues which can cause decreased milk production.

Key words: cows, heat stress, insulin sensitivity, metabolic profile.

\section{Introduction}

Heat stress represents state in which animal is exposed to high ambient temperatures. These temperatures are out of biological optimum. Because of those conditions, heat production by animal is greater than heat release. In this case, energy is being used for cooling in order to keep homoeothermia instead of being used for animal productivity (Cincović, 2016). Because of that heat stress of cows is characterized with reduced milk production and changed composition of milk (Cincović and Belić, 2009). Reduced productivity is consequence of reduced feed intake and metabolic and endocrine adaptations which are caused by direct influence of heat stress. Reduced feed intake causes decrease in glucose concentration in peripartal and lactating period. Increase in processes of lipolysis and ketogenesis are also noted (Bjerre-Harpoth et al., 2012). Cows during heat stress have reduced feed intake but lipolysis and ketogenesis are reduced. In addition, hormones that regulate homeostasis in lactation in heat stress lose this ability (Abeni et al., 2007; Cincović and Belić, 2011). Role of heat stress in these processes is experimentally proved. Ventilation of animals in heat stress results in stabilization of heat stress caused metabolic effects, concentrations of glucose and NEFA are increased and values of hormones and insulin sensitivity indexes are changed (Cincović et al., 2013). In high selected dairy cows lipolysis allows greater usage of fats in regular energetic and metabolic processes and glucose is being saved for milk production. In order to that reduced insulin production and insulin resistance occur.

Because of all listed above, metabolic changes that are consequence of direct heat stress can directly affect milk production. Dynamic changes of metabolite values can show animal adaptation to stress.

The aim of this study is to determine correlations between milk production and changes of metabolic parameters in cow under heat stress.

\section{Materials and methods}

Animals: Experiment included 30 Holstein-Frisian cows. Blood samples were collected in thermo-neutral period (May) and during heat stress (THI > 70, June). Milk yield was noted daily and date were given by farm software.

Sampling and laboratory analyses: Blood was taken from v. coccigea. Insulin concentration was determined with standard ELISA kit (Mercodia and Cusabio) 
on Rayto reader. NEFA and glucose concentrations were determined by spectrophotometric (Rayto) methods using standard Randox kits. RQUICKI index was calculated according to formula RQUICKI $=1 /[\log ($ glucose $\mathrm{mg} / \mathrm{dL}$ ) $+\log$ (insulin $\mu U / \mathrm{mL})+\log (\mathrm{NEFA} \mathrm{mmol} / \mathrm{l})]$. Insulin: NEFA and insulin: glucose rations were determined.

Statistics: Statistical differences were examined between insulin, glucose, NEFA values and indexes in thermo-neutral period and during heat stress using ttest. After that cows were classified to three groups, according to intensity in milk yield reduction. Those three groups were: cows with mild reduction in milk yield (below lower quartile), cows with moderate reduction in milk yield (quartile around median) and cows with severe milk yield reduction (above the upper quartile). It was descriptively showed in which percentage values of metabolites and indexes were changed during heat stress compared to thermoneutral period. Correlation between change in milk yield and metabolites values was determined. Border line in value of metabolic changes which will detect cows that have great reduction in milk production (above the upper quartile) (with $90 \%$ of specificity) was determined. That was done using a table $2 \times 2$ for every single of examined values.

\section{Results and discussion}

Cows under heat stress (high THI index) have reduced milk production, higher insulin concentration and lover levels of glucose and NEFA. Insulin sensitivity indexes- RQUICKI, insulin: glucose and insulin: NEFA have showed higher values in cows under heat stress. Results are showed in Table 1.

Classification of cows according to intensity of milk yield reduction have showed that trend of \% dropping of glucose and NEFA and trend of \% increase of insulin, RQUICKI index, insulin: glucose and insulin: NEFA were kept and increased with milk production reduction (Graphic 1). Significant correlations between listed parameters, as long as between listed parameters and milk yield were founded (Table 2).

Changes in metabolites values are of great importance for prediction of cows which are susceptible to drop in milk production (above 18\%). With nearly $90 \%$ of specificity cows that have severe reduction in milk yield can be detected. These cows have showed following changes during heat stress in comparison to thermo-neutral period: increased insulin levels for $\geq 12.5 \%$, reduction of NEFA for $\leq 14.1 \%$ and glucose for $\leq 21.5 \%$ and RQUICKI, insulin: NEFA, insulin: glucose increased for $\geq 9.6 \%, \geq 20.1$ and $\geq 20.3 \%$, respectively (Table 3 ). 
Table 1. Influence of heat stress on milk production and metabolic adaptation

\begin{tabular}{|c|c|c|c|}
\hline Parameter & $\begin{array}{c}\text { Thermo-neutral } \\
\text { period } \\
\text { Me }[95 \% \mathrm{CI}]\end{array}$ & $\begin{array}{c}\text { Heat stress } \\
\text { Me }[95 \% \mathrm{CI}]\end{array}$ & $\mathrm{p}$ \\
\hline Milk $(\mathrm{L} / \mathrm{dan})$ & $27.6[24.3-31.1]$ & $23.1[21.2-26.5]$ & $\mathrm{p}<0.05$ \\
\hline Insulin $(\mu \mathrm{U} / \mathrm{mL})$ & $6.2[4.9-7.3]$ & $7.3[5.8-9]$ & $\mathrm{p}<0.1$ \\
\hline NEFA $(\mathrm{mmol} / \mathrm{l})$ & $0.27[0.14-0.39]$ & $0.19[0.1-0.28]$ & $\mathrm{p}<0.05$ \\
\hline Glucose $(\mathrm{mg} / \mathrm{dL})$ & $47.2[43.1-51]$ & $36.3[33.2-39.1]$ & $\mathrm{p}<0.05$ \\
\hline RQUICKI & $0.52[0.40-0.64]$ & $0.62[0.55-0.71]$ & $\mathrm{p}<0.1$ \\
\hline Insulin: NEFA & $22.85[21-26]$ & $37.37[35-41]$ & $\mathrm{p}<0.05$ \\
\hline Insulin: glucose & $2.41[2.1-2.7]$ & $3.55[3.1-4.6]$ & $\mathrm{p}<0.05$ \\
\hline
\end{tabular}

Graphic 1. Changes of metabolites values and milk production (1- mild reduction in milk production- below lower quartile, 2- reduction in milk yield around median quartile, 3- severe milk yield reduction, above the upper quartile) during heat stress in comparison to thermo-neutral period.

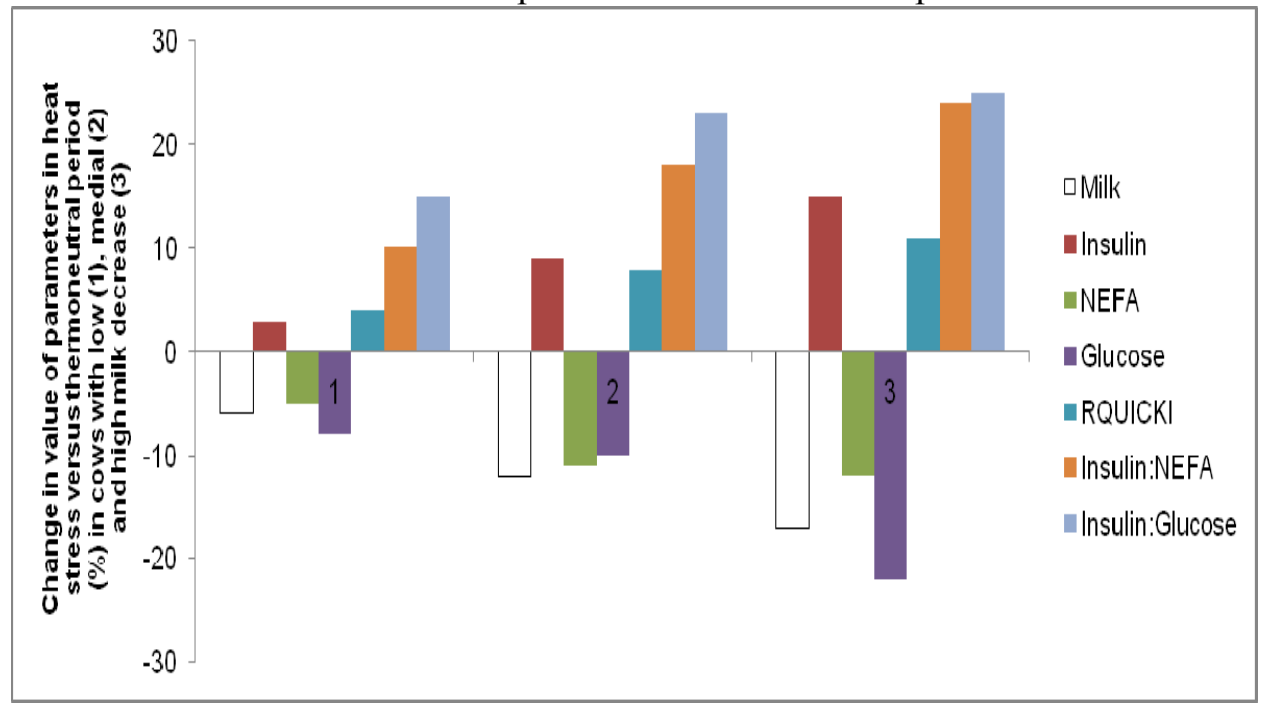


Table 2. Correlations between changes of metabolites values and milk production

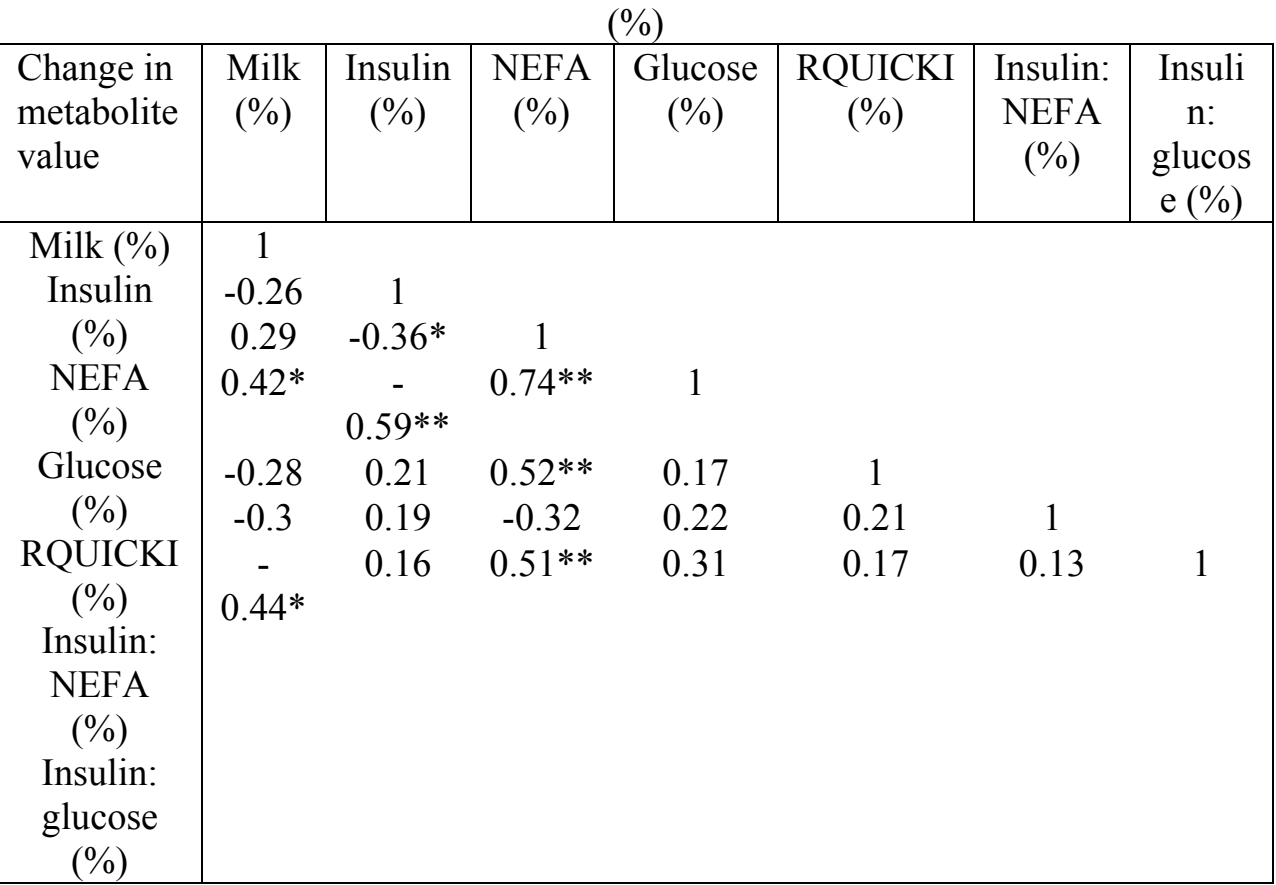

Table 3. Border limit values of metabolites which with $90 \%$ specificity indicate cows susceptible to great reduction in milk production during heat stress (above 18\%)

\begin{tabular}{|c|c|c|c|c|c|}
\hline & Value & Specificity & Sensitivity & $\begin{array}{c}\text { OR } \\
\text { (Odds } \\
\text { ration) }\end{array}$ & $\mathrm{p}$ \\
\hline Insulin (\%) & $\geq 12.5$ & 89.4 & 10.6 & 1.2 & $\mathrm{p}<0.1$ \\
\hline NEFA (\%) & $\leq 14.1$ & 88.1 & 11.9 & 1.1 & $\mathrm{p}<0.1$ \\
\hline Glucose (\%) & $\leq 21.5$ & 92.1 & 7.9 & 2.3 & $\mathrm{p}<0.01$ \\
\hline $\begin{array}{c}\text { RQUICKI } \\
\text { (\%) }\end{array}$ & $\geq 9.6$ & 90.7 & 9.3 & 1.7 & $\mathrm{p}<0.05$ \\
\hline $\begin{array}{c}\text { Insulin: } \\
\text { NEFA (\%) }\end{array}$ & $\geq 20.1$ & 89.8 & 10.2 & 1.9 & $\mathrm{p}<0.05$ \\
\hline $\begin{array}{c}\text { Insulin: } \\
\text { glucose (\%) }\end{array}$ & $\geq 20.3$ & 91.3 & 8.7 & 1.5 & $\mathrm{p}<.05$ \\
\hline
\end{tabular}


Ganter et al. (2011) noticed that milk production in cows is constant as long as ambient temperatures are low to middle. Rhoads et al. (2009) concluded that in summer time milk production can be reduced for $35 \%$. Reduction in milk production is consequence of reduced feed intake and negative energy balance. This is consistent with results of Rejeb et al. (2012). They examined milk production in cows during spring and summer. Results showed that losses during summer season are $600-900 \mathrm{~kg}$ of milk/ cow/ lactation. Period of lactation also have a great influence on milk production. Cows in middle lactation are especially sensitive. Increase of milk yield is followed with increased production of heat (cow that weight $450 \mathrm{~kg}$ for every $0.45 \mathrm{~kg}$ of milk releases $10 \mathrm{kcal}$ of heat). Cows in beginning of lactation use their body fats for energy needs, but in middle period of lactation organism depends on feed intake. During heat stress reduced feed intake and negative energy balance are present and they are cause of reduced milk production (Bernabucci et al., 2010).

According to given results it can be concluded that during heat stress metabolites (NEFA, glucose, insulin), that represent parameters of energy status of organism in lactation, are reduced.

Loss of appetite reduced feed intake and negative energy balance can cause reduction of glucose level. Reduced feed intake is consequence of calorific effect of food digestion. Organism tries to save itself from another heat wave by reducing feed intake (West, 2003). Other reason would be that glucose is predominantly used for metabolic processes. Catabolism of glucose release lower amounts (13\% less) of energy compared to fat catabolism (Cincović, 2016). Reduced glucose concentration can be explained by higher amount of circulating insulin. That insulin increase cell sensitivity to glucose, allows glucose to enter the cell where it can be further metabolized (Itoh et al., 1998). Whiteman et al., (2002) proved that increase of insulin concentration is related to expression of GLUT- 4 mRNA genes which stimulate synthesis of GLUT-4 proteins in skeleton muscles and fat tissue. That leads to increase of insulin level. At the same time gluconeogenesis is suppressed, glycogen is being used as a source of glucoses. Kinetics of glycogen metabolism is regulated by concentrations of insulin (Gamberucci et al., 1996).

Wheelock et al. (2010) concluded that insulin values increased during heat stress $(0.58$ to $0.78 \mathrm{mmol} / \mathrm{L})$. Increase of insulin concentration can be a consequence of specific gene expression in muscle tissue. The other reason could be increase of prolactin concentration. Prolactin stimulates $\beta$ cell proliferation and reduces GSIS (glucose- stimulated insulin secretion). In the other hand, usage of glucose by $\beta$ cells is increased. Insulin also shows antilipolytic effect reflected in reduced fat lipolysis, and metabolism is concentrated on carbohydrates (She, 1997).

Reduced concentrations of NEFA can be explained by reduced ability of lipid mobilization and with higher insulin sensitivity. Ronchi et al. (1999) concluded that reduced NEFA levels can be a result of great lipid uptake by liver which is 
very active during heat stress. Cincović et al. (2011) examined and concluded that during heat stress great reduction of NEFA and glucose levels occured. Wheelock et al. (2010) showed similar results where NEFA values during heat stress were $260 \mu \mathrm{Eq} / \mathrm{L}$, while in thermo-neutral period they were $425,1 \mu \mathrm{Eq} / \mathrm{L}$. Glucose levels were slightly reduced during heat stress.

In conclusion, dynamic changes in metabolites concentrations and insulin sensitivity indexes significantly interact with milk production in cows under heat stress. Dropping of glucose and NEFA levels, among insulin levels and insulin sensitivity increased, indicate that cows in heat stress transfer glucose from udder to other tissues. That causes reduction of milk production.

\section{Acknowledgement}

This experiment is result of project „Examining high ambient temperature influence on zoohigienic farm parameters and metabolic adaptation of cows towards achieving sustainable milk production in different climates" financed by Provincial Secretariat for high education and science-research work AP Vojvodina.

\section{References}

Abeni F., Calamari L., Stefanini L. (2007): Metabolic conditions of lactating Friesian cows during the hot season in the Po valley. Blood indicators of heat stress. International journal of biometeorology, 52: 87-96

Baumgard L., Rhoads J. (2013): Effects of heat stress on postabsorptive metabolism and energetics. Annu. Rev. Anim. Biosci., 1: 311-337.

Bernabucci U., Lacetera N., Baumgard, L., Rhoads, R., Ronchi B., Nardone A. (2010): Metabolic and hormonal acclimation to heat stress in domesticated ruminants. Animal, 4: 1167-1183.

Bjerre-Harpøth V., Friggens N., Thorup V., Larsen T., Damgaard B., Ingvartsen K., Moyes K. (2012): Metabolic and production profiles of dairy cows in response to decreased nutrient density to increase physiological imbalance at different stages of lactation. Journal of Dairy Science, 95: 2362-2380,

Cincović M., Belić B. (2009): Uticaj termalnog stresa krava na količinu i kvalitet proizvedenog mleka. Veterinarski žurnal Republike Srpske 9: 53-56.

Cincović M., Belić B., Stevancević M., Lako B., Toholj B., Potkonjak A. (2010a): Diurnal variation of blood metabolite in dairy cows during heat stress, Contemporary agriculture 59: $300-305$.

Cincović M., Belić, B., Toholj B., Radović I., Vidović B. (2010b): The influence of THI values at different periods of lactation on milk quality and characteristics of lactation curve. Journal of Agricultural Sciences, 55: 235-241.

Cincović M., Belić B. (2011a): Metabolička adptacija na peripartalni i toplotni stress kod mlečnih krava. Veterinarski žurnal Republike Srpske, 11: 155-159.

Cincović M., Belić B., Potkonjak A., Stevančević M., Lako B., Radović I. (2011b): Metabolic acclimation to heat stress in farm housed Holstein 
cows with different body condition scores. African Journal of Biotechnology, 10: 10293-10303.

Cincović M., Belić B., Stevančević M., Toholj B., Đoković R. (2013): Produktivne i metaboličke karakteristike krava izložene ventilatorima tokom letnjeg perioda. Letopis naučnih radova Poljoprivrednog fakulteta, 37: 75-82

Cincović M. (2016): Metabolički stres krava. Monografija. Univerzitet u Novom Sadu, Poljoprivredni fakultet Novi Sad, Departman za veterinarsku medicinu.

Gantner V., Mijić P., Kuterovac K., Solić D., Gantner R. (2011): Temperature-humidity index values and their significance on the daily production of dairy cattle. Mljekarstvo, 61: 56-63.

Gamberucci A., Marcolong P., Fulceri R., Giunti R., Watkins S., Waddell I., Burchell A., A. Benedetti. (1996): Low levels of glucose-6-phosphate hydrolysis in the sarcoplasmic reticulum of skeletal muscle: involvement of glucose-6-phosphatase. Molecular membrane biology, 13: 103-108

Itoh F., Obara Y., Rose M., Fuse H., Hashimoto H. (1998): Insulin and glucagon secretion in lactating cows during heat exposure. Journal of animal science, 76: 2182-2189

Rhoads M., Rhoads R., VanBaale M., Collier R., Sanders S., We ber W., Baumgard, L. (2009): Effects of heat stress and plane of nutrition on lactating Holstein cows: I. Production, metabolism, and aspects of circulating somatotropin. Journal of Dairy Science, 92: 1986-1997.

Ronchi B., Bernabucci U., Lacetera N., Supplizi A., Nardone A. (1999): Distinct and common effects of heat stress and restricted feeding on metabolic status of Holstein heifers. Zoot. Nutr. Anim. 25:11-20.

Rejeb M., Najar T., M'Rad, M. (2012): The effect of heat stress on dairy cow's performance and animal behaviour. International Journal of Plant, Animal and Environmental Science, 2: 29-34.

She P. (1997): Regulation of carbohydrate metabolism by exogenous glucagon in lactating cows. PhD Thesis.

West J. (2003): Effects of heat-stress on production in dairy cattle. Journal of dairy science, 86 (6): 2131-2144.

Wheelock J., Rhoads R., VanBaale M., Sanders S., Baumgard L. (2010): Effects of heat stress on energetic metabolism in lactating Holstein cows. Journal of Dairy Science, 93: 644-655.

Whiteman E., Cho H., Birnbaum M. (2002): Role of Akt/protein kinase B in metabolism. Trends in endocrinology and metabolism: TEM 13: 444-451. 
Acta Agriculturae Serbica, Vol. XXII, 44(2017); 123-131

\title{
ISPITIVANJE POVEZANOSTI PROIZVODNJE MLEKA I METABOLIČKE ADAPTACIJE KRAVA U TOPLOTNOM STRESU
}

\author{
Mira Majkić ${ }^{1}$, Marko R. Cincović ${ }^{1}$, Branislava Belić ${ }^{1}$, \\ Nada Plavša ${ }^{1}$, Ivana Lakić ${ }^{1}$, Miodrag Radinović ${ }^{1}$ \\ ${ }^{1}$ Univerzitet u Novom Sadu, Poljoprivredni fakultet, Departman za \\ veterinarsku medicinu, Laboratorija za patološku fiziologiju, Novi Sad, \\ Srbija
}

\section{Rezime}

Cilj ovog rada je da se utvrdi povezanost između promena u proizvodnji mleka i metaboličke adaptacije kod krava izloženih toplotnom stresu. U ogled je uključeno 30 krava Holštajn-frizijske rase. Krave izložene termalnom stresu u vidu visokog THI indeksa imaju nižu proizvodnju mleka, višu koncentraciju insulina i nižu koncentraciju glukoze i NEFA. Indeksi insulinske senzitivnosti RQUICKI, insulin:glukoza i insulin:NEFA odnos pokazuju više vrednosti kod krava izloženih toplotnom stresu. Kada se krave klasifikuju na osnovu intenziteta u padu proizvodnje mleka, rezultati pokazuju da trend procentualnog opadanja glukoze i NEFA i trend procentualnog porasta insulina, RQUICKI indeksa, insulin:glukoza i insulin:NEFA se zadržava i pojačava sa opadanjem proizvodnje mleka. Pored navedenog nađena je značajnakorelacija između navedenih parametara i proizvodnje mleka, kao i međusobna korelacija između navedenih parametara. Promena u vrednosti metabolita je od velikog značaja za predikciju krava kod kojih će doći do značajnog opadanja u proizvodnji mleka (preko 18\%). Sa približno $90 \%$ specifičnosti možemo detektovati krave sa visokim opadanjem proizvodnje mleka. To su krave koje su imale sledeće relativne promene u vrednsti metabolita $\mathrm{u}$ toplotnom stresu u odnosu na termoneutralni period: porast vrednosti insulina za $\geq 12,5 \%$, pad vrednosti NEFA i glukoze za $\leq 14,1 \%$ odnosno $\leq 21,5 \%$ i porast vrednosti RQUICKI indeksa, insulin:NEFA i insulin:glukoza odnosa za $\geq 9,6 \%, \geq 20,1 \%$ i $\geq 20,3 \%$. Dinamičke promene u vrednostima metabolita i indeksa insulinske senzitivnosti značajno utiču na proizvodnju mleka kod mlečnih krava tokom izlaganja toplotnom stresu. Opadanje vrednosti glukoze uz porast vrednosti insulina i povećanje senzitivnosti na insulin ukazuju da kod krava u toplotnom stresu dolazi do preusmeravanja glukoze od vimena ka ostalim tkivima, što dovodi do padanja proizvodnje mleka.

Ključne reči: krave, toplotni stres, isnulinska senzitivnost, metabolički profil. 